\title{
Blood Flow Differences Between Leuko-araiosis With and Without Lacunar Infarction
}

\author{
Minoru Oishi, Yoko Mochizuki and Toshiaki Takasu
}

\begin{abstract}
Background: The present study was designed to find the differences in regional cerebral blood flow and cerebrovascular acetazolamide reactivity between leuko-araiosis with and without lacunar infarction. Methods: Fifteen cases of leuko-araiosis with lacunar infarction, 15 cases of leuko-araiosis without lacunar infarction and 15 age-matched controls in which leuko-araiosis and cerebrovascular diseases are absent (control group) were studied. The regional cerebral blood flow was measured using the stable xenon computed tomography method before and 20 minutes after intravenous injection of 17 $\mathrm{mg} / \mathrm{kg}$ acetazolamide. Results: The blood flows in the leuko-araiosis area and the lacunar area were significantly lower than the blood flow in the cerebral white matter. The blood flows in the cerebral cortex and the cerebral white matter were significantly lower in the leuko-araiosis with lacunar infarction group than in the leuko-araiosis without lacunar infarction group and the control group. The cerebrovascular acetazolamide reactivity in the leuko-araiosis area and the lacunar area was significantly lower than that in the cerebral white matter. The cerebrovascular acetazolamide reactivity in the cerebral cortex and the cerebral white matter was significantly lower in the leuko-araiosis with lacunar infarction group than in the leuko-araiosis without lacunar infarction group and the control group. Conclusions: The degree of arteriolosclerosis is considered to be more severe and the rate of association of hypertension was higher in leuko-araiosis with lacunar infarction than in leuko-araiosis without lacunar infarction.
\end{abstract}

RÉSUMÉ: Différence dans le débit sanguin dans la leucoaraïose avec et sans infarcissement lacunaire. Introduction: Cette étude a été conçue dans le but de mettre en évidence les différences dans le débit sanguin cérébral régional et dans la réactivité à l'acétazolamide dans la leucoaraïose avec et sans infarcissement lacunaire. Méthodes: Nous avons étudié 15 cas de leucoaraïose avec infarcissement lacunaire, 15 cas de leucoaraïose sans infarcissement lacunaire et 15 cas contrôles appariés pour l'âge qui ne présentaient pas de leucoaraïose ou de maladie vasculaire cérébrale (groupe contrôle). Nous avons mesuré le débit sanguin cérébral régional au moyen de la tomodensitométrie au xénon stable avant injection intraveineuse de $17 \mathrm{mg} / \mathrm{kg}$ d'acétazolamide et 20 minutes après. Résultats: Les débits sanguins dans les zones de leucoaraiose et d'infarcissement lacunaire étaient signficativement plus faibles que les débits sanguins dans la substance blanche. Les débits sanguins dans le cortex et dans la substance blanche étaient signficativement plus faibles dans le groupe avec leucoaraïose et infarcissement lacunaire que dans le groupe avec leucoaraïse sans infarcissement lacunaire et dans le groupe contrôle. La réactivité vasculaire cérébrale à l'acétazolamide dans les zones de leucoaraïose et dans les zones lacunaires était significativement plus faible que dans la substance blanche. La réactivité vasculaire cérébrale à l'acétazolamide dans le cortex et dans la substance blanche était significativement plus faible dans le groupe avec leucoaraïose avec infarcissement lacunaire que dans le groupe avec leucoaräose sans infarcissement lacunaire et dans le groupe contrôle. Conclusion: Nous avons observé une artériolosclérose plus sévère et une prévalence plus élevée d'hypertension dans la leucoaraïose avec infarcissement lacunaire que dans la leucoaraïose sans infarcissement lacunaire.

Can. J. Neurol. Sci. 1998; 25: 70-75

Leuko-araiosis is a radiological finding and its pathophysiology is not uniform. ${ }^{1.2}$ Leuko-araiosis on computed tomography or magnetic resonance imaging is considered to be mainly due to demyelination and gliosis ${ }^{3-5}$ and stenosis or occlusion of deep cerebral veins may promote development of leuko-araiosis. ${ }^{6}$ Leuko-araiosis is frequently associated with lacunar infarction ${ }^{7}$ and the prognosis of lacunar infarction with leuko-araiosis was reported to be worse than that of lacunar infarction without leuko-araiosis. ${ }^{8}$ The cerebral blood flow has been reported to be decreased in leuko-araiosis ${ }^{9-12}$ and in silent lacunar infarction ${ }^{13}$ but there are no reports on the differences of regional cerebral blood flow and the cerebrovascular acetazolamide reactivity

From the Department of Neurology, Nihon University School of Medicine, Tokyo, Japan.

RECEIVED APRIL 8, 1997. ACCEPTED IN FINAL FORM JULY 7, 1997.

Reprint requests to: Minoru Oishi, M.D., Department of Neurology, Nihon University Nerima Hikarigaoka Hospital, 2-11-1 Hikarigaoka, Nerima-ku, Tokyo 179, Japan 
between leuko-araiosis with lacunar infarction and leuko-araiosis without lacunar infarction. Therefore, we measured regional cerebral blood flow before and after intravenous injection of acetazolamide in patients with leuko-araiosis.

\section{Subjects And Methods}

Fifteen cases of leuko-araiosis with lacunar infarction, 15 cases of leuko-araiosis without lacunar infarction and 15 agematched controls in which leuko-araiosis and cerebrovascular diseases are absent (control group) were studied with their informed consent. These patients were prospectively enrolled into the study. The patients with leuko-araiosis were admitted to our hospital and head computed tomography (CT), head magnetic resonance imaging (MRI), echocardiography and blood viscosity were studied on the patients. Subcortical cystic infarctions with a diameter of less than $1.5 \mathrm{~cm}$ were diagnosed as lacunar infarction. ${ }^{14}$ The patients with hydrocephalus, leukodystrophy and lacunar infarction in the acute stage were excluded from this study. Medications such as cerebral vasodilators which influence cerebral blood flow were discontinued 2 weeks prior to the cerebral blood flow examination. Fifteen cases in each group were selected by the order of admission date. Table 1 shows the subjects' characteristics in the 3 groups.

The degree of white matter lesions was graded using the method of Kobari et al. ${ }^{15}$ and the degree of white matter lesions in anterior and posterior regions was graded using the method of van Swieten et al. ${ }^{16}$

The regional cerebral blood flow was measured using the stable xenon CT method. ${ }^{17.18}$ The basal ganglia section and the lateral ventricle section parallel to the orbito-meatal line were studied. The subjects inhaled room air followed by a mixture of $30 \%$ xenon and $50 \%$ oxygen for 3 minutes. Serial scanning was performed once before xenon inhalation, three times in the washin process and five times in the washout process of $5 \mathrm{~min}$ utes. The serial scanning program consisted of a total of 18 scans consisting of 9 serial scans on each section. The xenon concentration in the end-tidal expired gas was continuously recorded by the thermoconductivity method. We used the xenon delivery and analysis system (AZ-7000 model, Anzai Sogyo, Tokyo, Japan) and the CT equipment (PreSage, Yokogawa Medical Systems, Tokyo, Japan).

Regional cerebral blood flows were measured in the leukoaraiosis area, in the lacunar infarction area, and in the cerebral cortex and cerebral white matter where the influence of the leuko-araiosis and the lacunar infarction was considered to be little. Round region of interest (ROI) with a diameter of $7 \mathrm{~mm}$ was used and the ROI was placed in the center of each leukoaraiosis area in bilateral anterior and posterior regions. The leuko-araiosis area blood flow was calculated as the average of the blood flows in the 4 leuko-araiosis areas. Out of 15 cases of leuko-araiosis with lacunar infarction, 6 had lacunar infarction in the thalamus, 5 had lacunar infarction in the frontal white matter and 4 had multiple lacunar infarctions. The lacunar infarction area blood flow was measured placing the ROI in the lacunar area. In bilateral frontal lobes, parietal lobes, temporal lobes and occipital lobes, the ROI was placed in the area where leuko-araiosis and lacunar infarction were not adjacent and direct nerve fiber connection with the lacunar infarction area. The cerebral cortex blood flow and cerebral white matter blood flow were calculated as the average of the blood flows in the 8 areas.

Arterial $\mathrm{CO}_{2}$ tension was measured before the examination, 20 minutes after intravenous injection of acetazolamide and after the examination.

Statistical analysis was performed using Mann-Whitney's U tests for comparison of the cerebral blood flows and using Fisher's exact probability tests for comparison of risk factors among the 3 groups.

\section{Results}

Figure I shows head magnetic resonance imaging and CT scan in a case of leuko-araiosis with lacunar infarction. Figure 2 shows head magnetic resonance imaging and CT scan in a case of leuko-araiosis without lacunar infarction. The degree of leuko-araiosis did not show any significant difference between the leuko-araiosis with lacunar infarction group and the leukoaraiosis without lacunar infarction group (Table 2). The rate of association of hypertension was significantly higher in the leuko-araiosis with lacunar infarction group than in the leukoaraiosis without lacunar infarction group and the control group (Table 1).

Figure 3 shows the actual record of xenon CT before and after intravenous injection of acetazolamide. Table 2 shows the mean and standard deviation of the regional cerebral blood flows. The blood flows in the leuko-araiosis area and the lacunar area were significantly lower than the blood flow in the cerebral

Table 1: Subjects' Characteristics in 3 Groups.

\begin{tabular}{lccc}
\hline & $\begin{array}{c}\text { Leuko-araiosis with } \\
\text { Lacunar Infarction Group }\end{array}$ & $\begin{array}{c}\text { Leuko-araiosis without } \\
\text { Lacunar Infarction Group }\end{array}$ & $\begin{array}{c}\text { Age-matched Controls } \\
\text { (Control Group) }\end{array}$ \\
Number of subjects & 15 & 15 & 15 \\
Age (years)* & $67.7 \pm 8.3$ & $68.2 \pm 8.5$ & $67.9 \pm 8.6$ \\
Male:female & $7: 8$ & $8: 7$ & $8: 7$ \\
Hypertension & $12 / 15 \dagger$ & $3 / 15$ & $4 / 15$ \\
Diabetes mellitus & $3 / 15$ & $2 / 15$ & $2 / 15$ \\
Hyperlipidemia & $5 / 15$ & $6 / 15$ & $4 / 15$ \\
mini-mental state examination score* & $22 \pm 5 \#$ & $26 \pm 5$ & $30 \pm 0$ \\
*mean \pm standard deviation. & & & \\
† P <.01 compared with the other two groups. & & \\
$\# \mathrm{P}<.01$ compared with the control group. & & \\
\hline
\end{tabular}




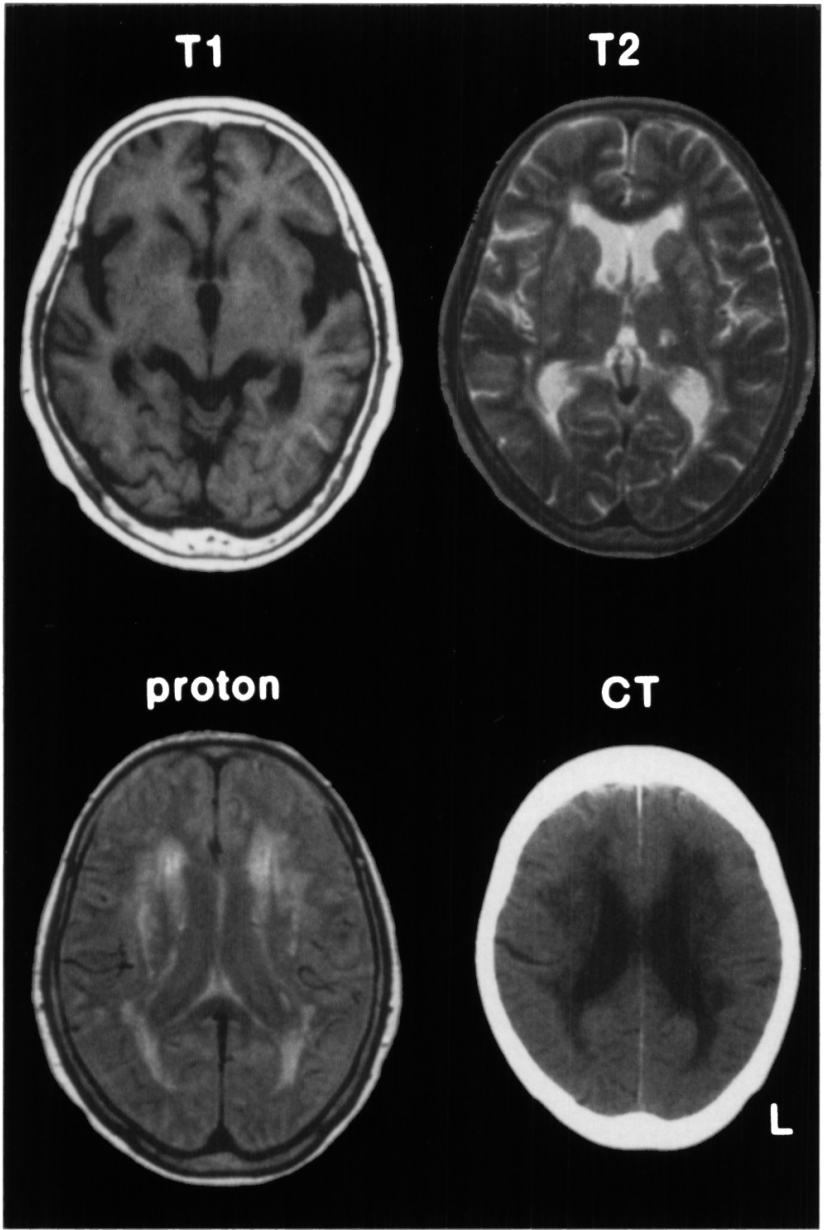

Figure 1: Head magnetic resonance imaging and $C T$ scan in a case of leuko-araiosis with lacunar infarction.

white matter. The blood flows in the cerebral cortex and the cerebral white matter where the influence of the leuko-araiosis and the lacunar infarction was considered to be little were significantly lower in the leuko-araiosis with lacunar infarction group than in the leuko-araiosis without lacunar infarction group and the control group. The cerebrovascular acetazolamide reactivity in the leuko-araiosis area and the lacunar area was significantly lower than that in the cerebral white matter. The cerebrovascular acetazolamide reactivity in the cerebral cortex and the cerebral white matter where the influence of the leuko-araiosis and the lacunar infarction was considered to be little was significantly lower in the leuko-araiosis with lacunar infarction group than in the leuko-araiosis without lacunar infarction group and the control group (Table 3 ).

Arterial $\mathrm{CO}_{2}$ tension did not show any significant difference between before and after the examination and between before and 20 minutes after the intravenous injection of acetazolamide.

\section{Discussion}

Leuko-araiosis has many causes, ${ }^{2}$ but the common causes are considered to be arteriolosclerosis ${ }^{7,11,19}$ and normal aging. ${ }^{10,20}$ Cerebral blood flow has been reported to be decreased in leukoaraiosis; ${ }^{13-15,21}$ however, leuko-araiosis is frequently associated with lacunar infarction and mean regional cerebral blood flow

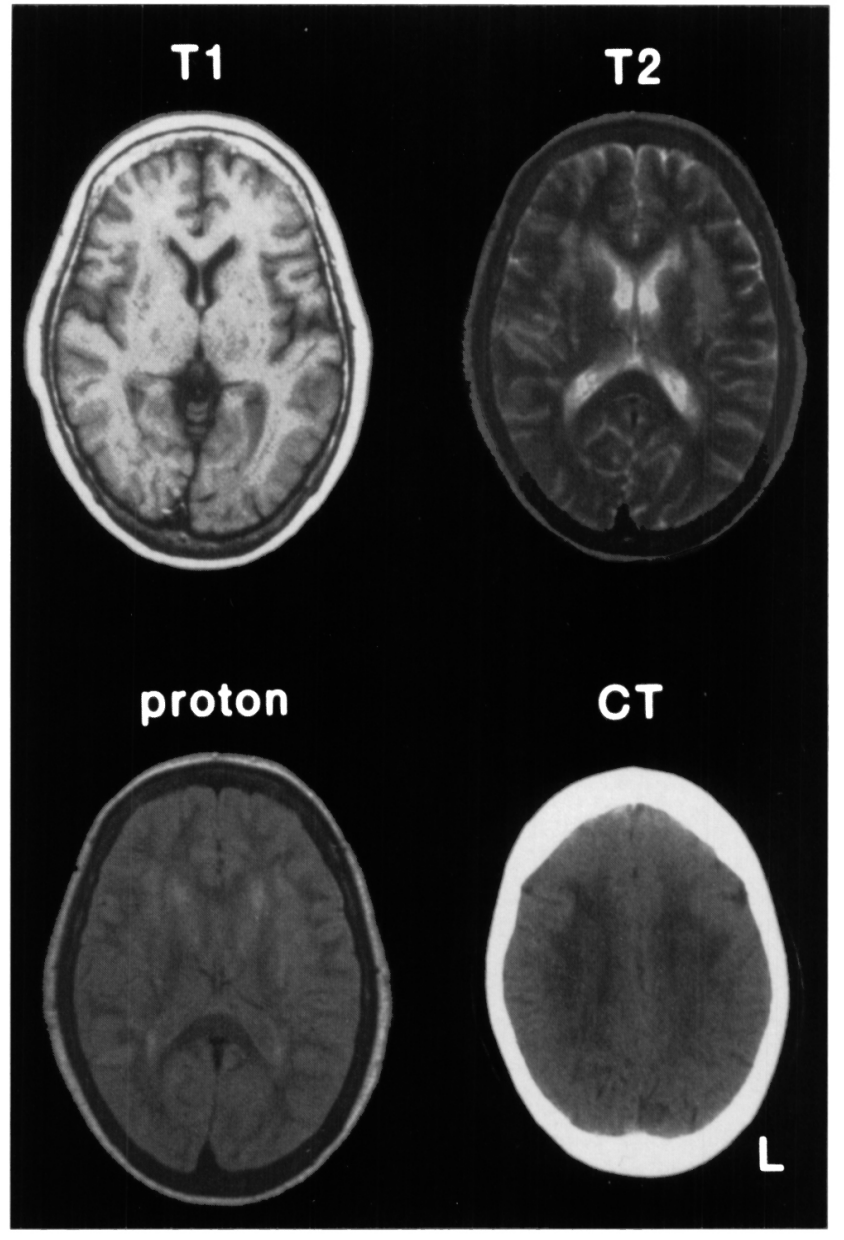

Figure 2: Head magnetic resonance imaging and CT scan in a case of leuko-araiosis without lacunar infarction.

has been reported to be decreased in lacunar infarction. ${ }^{13}$ Because the decreased cerebral blood flow in leuko-araiosis may be related to lacunar infarction, we compared the cerebral blood flow between the leuko-araiosis with lacunar infarction group and the leuko-araiosis without lacunar infarction group.

Acetazolamide is considered to dilate the cerebral arterioles by inhibiting the carbonic anhydrase in the red blood cells and increasing $\mathrm{CO}_{2}$ in the arterioles. ${ }^{22}$ Acetazolamide has been used for examining cerebrovascular dilatory reserve capacity. ${ }^{23}$ Yamamoto et al. ${ }^{24}$ reported that cerebrovascular $\mathrm{CO}_{2}$ reactivity was mildly decreased in arteriosclerosis due to normal aging, moderately decreased in normal persons with risk factors of cerebral arteriosclerosis, and markedly decreased in cerebrovascular diseases and that $\mathrm{CO}_{2}$ inhalation is a useful screening examination in cerebral arteriosclerosis. Acetazolamide has a cerebrovascular dilating effect similar to $\mathrm{CO}_{2}{ }^{25}$ and decreased acetazolamide reactivity is considered to suggest arteriosclerosis.

In the present study, cerebrovascular acetazolamide reactivity was decreased in the leuko-araiosis area. This suggests that cerebrovascular dilatory reserve capacity is decreased in the leuko-araiosis area. The blood flow and acetazolamide reactivity in the cerebral cortex were significantly lower in the leukoaraiosis with lacunar infarction group than in the leuko-araiosis without lacunar infarction group in the present study. This 
Table 2: Grades of White Matter Lesions in 3 Groups (mean \pm standard deviation).

Leuko-araiosis with Leuko-araiosis without Control Group Lacunar Infarction Group Lacunar Infarction Group

Grades according to Kobari et al. ${ }^{16}$

Periventricular high-intensity signals on T2-weighted MRI

Remote high-intensity signals in subcortical white matter on

T2-weighted MRI that are unrelated to neurologic deficits

Periventricular hypodense areas on CT

Cerebral atrophy on both MRI and CT

$$
\begin{aligned}
& 2.8 \pm 0.8 \\
& 2.0 \pm 0.7 \\
& 1.8 \pm 0.8 \\
& 1.3 \pm 0.5
\end{aligned}
$$

$2.9 \pm 0.8$

$0.3 \pm 0.5^{\circ}$

Grades according to van Swieten et al. ${ }^{17}$

Anterior region on CT

Posterior region on CT

Both regions together on CT

Anterior region on MRI

Posterior region on MRI

$2.1 \pm 0.6$
$1.9 \pm 0.8$
$1.4 \pm 0.5$

$0.1 \pm 0.4^{a}$

$0.0 \pm 0.0^{\mathrm{a}}$

Both regions together on MRI

$\begin{array}{ll}1.5 \pm 0.5 & 1.5 \pm 0.5 \\ 1.3 \pm 0.5 & 1.4 \pm 0.5 \\ 2.8 \pm 0.9 & 2.9 \pm 1.0 \\ 1.7 \pm 0.5 & 1.8 \pm 0.4 \\ 1.7 \pm 0.5 & 1.7 \pm 0.5 \\ 3.4 \pm 0.9 & 3.5 \pm 0.8\end{array}$

$0.0 \pm 0.0^{a}$

$0.0 \pm 0.0^{\mathrm{a}}$

$0.0 \pm 0.0^{\circ}$

$0.3 \pm 0.5$ a

$0.2 \pm 0.4$ a

$0.5 \pm 0.8^{\mathrm{a}}$

uP $<.01$ compared with the other two groups.

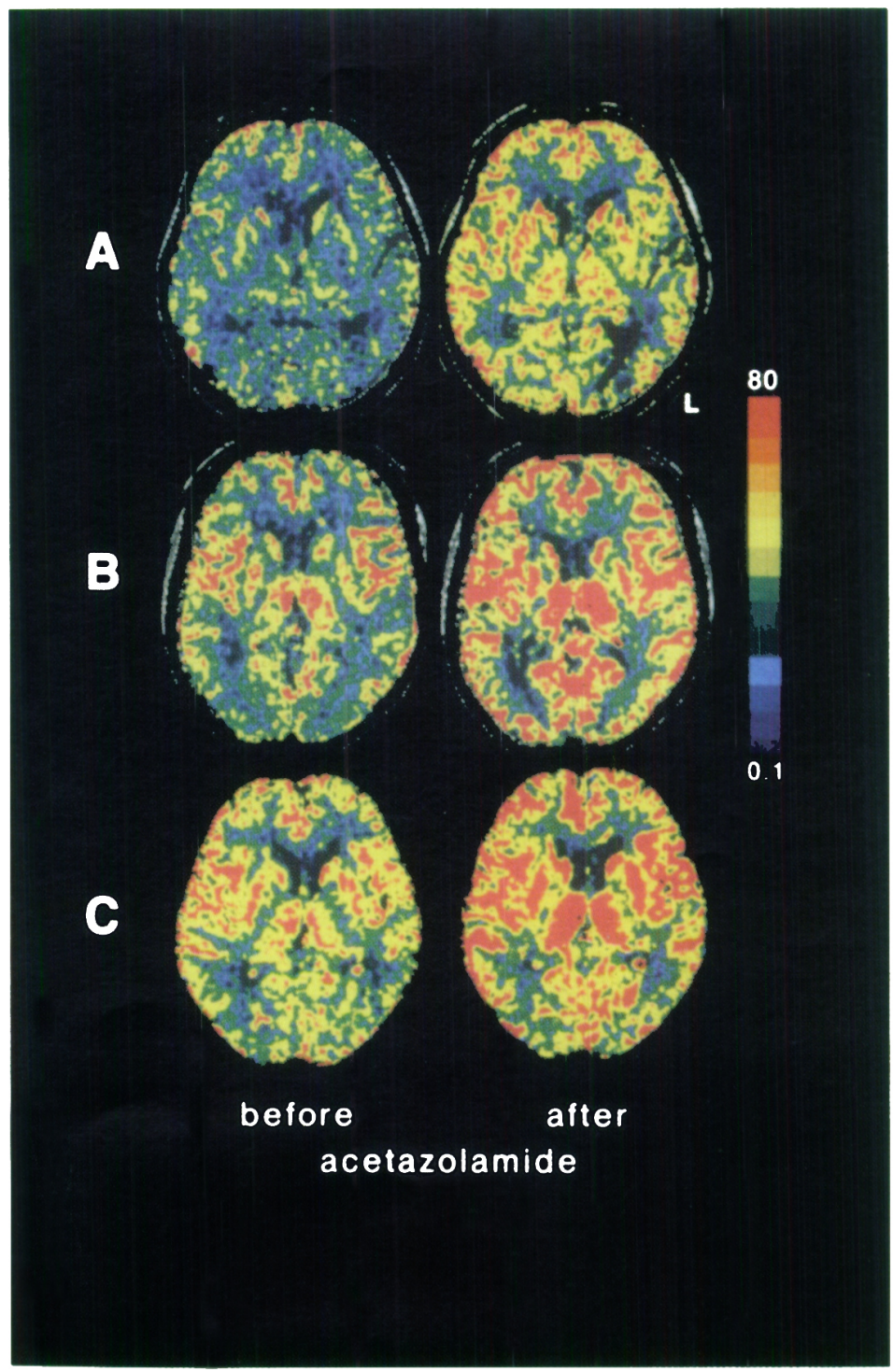

Figure 3: Actual record of xenon computed tomography before and after intravenous injection of acetazolamide. A: leuko-araiosis with lacunar infarction, $B$ : leuko-araiosis without lacunar infarction, $C$ : control. Before the intravenous injection of acetazolamide, the cerebral blood flow is lower in $A$ than in $B$ and $C$. After the intravenous injection of acetazolamide, the increase rate in cerebral blood flow is less in $A$ than in $B$ and $C$. 
Table 3: The Blood Flow ( $\mathrm{ml} / \mathrm{l00g} / \mathrm{min})$ Before the Intravenous Injection of Acetazolamide and the Increase Rate (\%) in Blood Flow by the Intravenous Injection of Acetazolamide (mean \pm standard deviation).

\section{Leuko-araiosis with Leuko-araiosis without Control Group \\ Lacunar Infarction Group Lacunar Infarction Group}

Before the intravenous injection of acetazolamide

Cerebral cortex blood flow

Cerebral white matter blood flow

Leuko-araiosis area blood flow

Lacunar infarction area blood flow

After the intravenous injection of acetazolamide

Increase rate in cerebral cortex blood flow

Increase rate in cerebral white matter blood flow

Increase rate in leuko-araiosis area blood flow

Increase rate in lacunar infarction area blood flow

ap $<.01$ compared with the other two groups.

${ }^{\mathrm{b}} \mathrm{P}<.01$ compared with the cerebral white matter.

$\begin{array}{ccc}42.6 \pm 6.5^{\mathrm{a}} & 50.7 \pm 7.5 & 57.4 \pm 7.3 \\ 20.1 \pm 4.2^{\mathrm{a}} & 27.8 \pm 4.1 & 28.6 \pm 4.3 \\ 15.7 \pm 2.7^{\mathrm{b}} & 17.2 \pm 2.6^{\mathrm{b}} & - \\ 12.4 \pm 3.6^{\mathrm{b}} & - & -\end{array}$

$35.7 \pm 6.3^{a}$

$37.8 \pm 6.9^{\mathrm{a}}$

$26.2 \pm 5.6^{\mathrm{b}}$

$24.7 \pm 5.5^{b}$
$55.4 \pm 8.1$

$45.6 \pm 7.8$

$52.9 \pm 8.2$

$34.5 \pm 6.9^{b}$

$-$ suggests that the degree of arteriolosclerosis may be more severe in leuko-araiosis with lacunar infarction than in leukoaraiosis without lacunar infarction. The leuko-araiosis may be divided into leuko-araiosis with lacunar infarction, in which arteriolosclerosis ${ }^{7.19}$ is the commonest cause, and leuko-araiosis without lacunar infarction, in which axonal degeneration associated with normal aging ${ }^{26}$ is the commonest cause.

The rate of association of hypertension was higher in the leukoaraiosis with lacunar infarction group than in the leuko-araiosis without lacunar infarction group and the mini-mental state examination score ${ }^{27}$ was worse in the leuko-araiosis with lacunar infarction group than in the control group in the present study. This suggests that the pathophysiology is different between leuko-araiosis with lacunar infarction and leuko-araiosis without lacunar infarction. Because the sample size is small in the present study, we hope that a study with a large sample size will be performed.

\section{ACKNOWLEDGEMENTS}

This research was supported by the Nihon University Ozawa Research Grant.

\section{REFERENCES}

I. Hachinski VC, Potter P, Merskey H. Leuko-araiosis: An ancient term for a new problem. Can J Neurol Sci 1986; 13: 533-534.

2. Verny M, Duyckaerts C, Pierot L, Hauw J-J. Leuko-araiosis. Dev Neurosci 1991; 13: 245-250.

3. Sze G, De Armond SJ, Brant-Zawadzki M, et al. Foci of MRI signal (pseudo lesions) anterior to the frontal horns: histologic correlations of a normal finding. Am J Radiol 1986; 147: 331-337.

4. Révész T, Hawkins CP, du Boulay EPGH, Barnard RO, McDonald WI. Pathological findings correlated with magnetic resonance imaging in subcortical arteriosclerotic encephalopathy (Binswanger's disease). J Neurol Neurosurg Psychiatry 1989; 52: 1337-1344.

5. Leifer D, Buonanno FS, Richardson EP Jr. Clinicopathologic correlations of cranial magnetic resonance imaging of periventricular white matter. Neurology 1990; 40: 911 -918.

6. Moody DM, Brown WR, Challa VR, Anderson RL. Periventricular venous collagenosis: association with leukoaraiosis. Radiology 1995; 194: 469-476.

7. Hijdra A, Verbeeten B Jr, Verhulst JAMP. Relation of leukoaraiosis to lesion type in stroke patients. Stroke 1990; $21: 890-894$.
8. Miyao S, Takano A, Teramoto J, Takahashi A. Leukoaraiosis in relation to prognosis for patients with lacunar infarction. Stroke 1992; 23: 1434-1438.

9. Kobari M, Meyer JS, Ichijo M. Leuko-araiosis, cerebral atrophy, and cerebral perfusion in normal aging. Arch Neurol 1990; 47: 161-165.

10. Kawamura J, Meyer JS, Terayama Y, Wethers S. Leuko-araiosis correlates with cerebral hypoperfusion in vascular dementia. Stroke 1991; 22: 609-614.

11. Yao H, Sadoshima S, Ibayashi S, et al. Leukoaraiosis and dementia in hypertensive patients. Stroke 1992; 23: 1673-1677.

12. Turc J-D, Chollet F, Berry I, et al. Cerebral blood flow, cerebral blood flow reactivity to acetazolamide, and cerebral blood volume in patients with leukoaraiosis. Cerebrovasc Dis 1994; 4: 287-293.

13. Kobayashi S, Okada K, Yamashita K. Incidence of silent lacunar lesion in normal adults and its relation to cerebral blood flow and risk factors. Stroke 1991; 22: 1379-1383.

14. National Institute of Neurological Disorders and Stroke. Classification of cerebrovascular diseases III. Stroke 1990; 21: 637-676.

15. Kobari M, Meyer JS, Ichijo M, Oravez WT. Leukoaraiosis: correlation of MR and CT findings with blood flow, atrophy, and cognition. Am J Neuroradiol 1990; 11: 273-281.

16. van Swieten JC, Hijdra A, Koudstaal PJ, van Gijn J. Grading white matter lesions on CT and MRI: a simple scale. J Neurol Neurosurg Psychiatry 1990; 53: 1080-1083.

17. Johnson DW, Stringer WA, Marks MP, et al. Stable xenon CT cerebral blood flow imaging: rationale for and role in clinical decision making. Am J Neuroradiol 1991; 12: 201-213.

18. Kashiwaki S, Yamashita T, Nakano S, et al. The wash-in/washout protocol in stable xenon CT cerebral blood flow studies. Am J Neuroradiol 1992; 13: 49-53.

19. van Swieten JC, van den Hout JHW, van Ketel BA, et al. Periventricular lesions in the white matter on magnetic resonance imaging in the elderly. Brain 1991; 114: 761-774.

20. Hunt AL, Orrison WW, Yeo RA, et al. Clinical significance of MRI white matter lesions in the elderly. Neurology 1989; 39: 14701474.

21. de Reuck J, Decoo D, Lemahieu I, Strijckmans K, Goethals P. Is the leuko-araiosis-dementia syndrome different from Binswanger's subcortical atherosclerotic encephalopathy? J Stroke Cerebrovasc Dis 1992; 2: 225-227

22. Frankel HM, Gracia E, Malik F, Weiss JK, Weis HR. Effect of acetazolamide on cerebral blood flow and capillary patency. $J$ Appl Physiol 1992; 73: 1756-1761.

23. Sullivan HG, Kingsbury TB, Morgan ME, et al. The $\mathrm{rCBF}$ response to Diamox in normal subjects and cerebrovascular disease patients. J Neurosurg 1987; 67: 525-534. 
24. Yamamoto M, Meyer JS, Sakai F, Yamaguchi F. Aging and cerebral vasodilator responses to hypercarbia. Arch Neurol 1980;37: 489-496.

25. Ringelstein EB, Eyck SV, Mertens I. Evaluation of cerebral vasomotor reactivity by various vasodilating stimuli: comparison of CO2 to acetazolamide. J Cereb Blood Flow Metab 1992; 12: 162-168.
26. Meyer JS, Takashima S, Terayama Y, et al. CT changes associated with normal aging of the human brain. J Neurol Sci 1994: 123: 200-208.

27. Folstein MF, Folstein SE, McHugh PR. "Mini-mental state" a practical method for grading the cognitive state of patients for the clinician. J Psychiat Res 1975; 12: 189-198. 